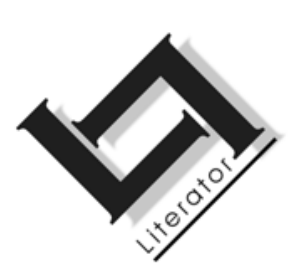

\title{
Memory, history and oblivion in Horre/poot by Eben Venter
}

\author{
M. Postma \& M.N. Slabbert \\ Department of Jurisprudence \\ University of South Africa \\ PRETORIA \\ E-mail: mariette@postma.co.za \\ slabbmn@unisa.ac.za
}

The mind of man is capable of anything - because everything is in it, all the past as well as all the future. What was there after all? Joy, fear, sorrow, devotion, valour, rage who can tell? - but truth - truth stripped of its cloak of time. (Conrad, 1983:69)

\begin{abstract}
Memory, history and oblivion in Horrelpoot by Eben Venter

"Horrelpoot" by Eben Venter joins the ranks of other postapartheid Afrikaans literature that reflects different sides of memory, history and guilt. This article explores the different constructs of memory - laced with rich Jungian archetypal images - that are portrayed in "Horrelpoot". Drawing on Joseph Conrad's "Heart of Darkness", "Horrelpoot" sketches the protagonist, Marlouw's journey from the West (Australia) to the "dark" continent (Africa), and his ancestral farm, "Ouplaas" in South Africa. The article elaborates on Marlouw's journey, which, at a deeper level, is nothing but a Jungian journey towards individuation, a journey into the deepest and archaic level of his own psyche. In the final instance, "Horrelpoot" reminds us that in a century of forgetting, memory persists, and that Marlouw's journey could be a collective one which may guide white South Africans to face their own deep and dark past and the horror that lies at the bottom of their history.
\end{abstract}




\section{Opsomming}

\section{Geheue, geskiedenis en vergetelheid in Horrelpoot deur Eben Venter}

"Horrelpoot" deur Eben Venter pas in die kategorie van Afrikaanse postapartheid letterkunde wat gemoeid is met die verskillende fasette van herinnering, geskiedenis en skuld. Hierdie artikel ondersoek die verskillende konstruksies van herinnering, nóú verweef met jungiaanse argetipiese beelde, wat in "Horrelpoot" vergestalt word. Die roman, sterk beïnvloed deur Joseph Conrad se "Heart of Darkness", skets die protagonis, Marlouw, se reis van die Weste (Australië) na die "donker" kontinent, Afrika, en spesifiek na sy voormalige familieplaas, "Ouplaas" in Suid-Afrika. Die artikel borduur voort op Marlouw se reis, wat op 'n dieper vlak, niks anders is nie as 'n jungiaanse reis gerig op individuasie, 'n reis wat reik tot in die diepste en mees argaiëse vlak van sy psige. "Horrelpoot" herinner ons dat in 'n eeu van vergeet, herinnering altyd sal deurbreek, en dat Marlouw se reis ook 'n kollektiewe een kan wees wat alle Suid-Afrikaners kan lei om hulle eie en donker verlede, die verskrikking wat agter hulle eie geskiedenis lê, te konfronteer.

\section{Introduction}

He wanted no more than justice ... he seemed to stare at me ... with that wide and immense stare embracing, condemning, loathing all the universe. I seemed to hear the whispered cry, The horror! The horror! (Conrad, 1983:117.)

Eben Venter's recent novel, Horrelpoot (2006), ${ }^{1}$ sketches the return and attempted intervention of the white protagonist, Marlouw, from Australia to his ancestral farm in South Africa, ostensively to find his sister's son, Koert. His native country seems to be disintegrating in many ways, and he sees drought, ruin and devastation all around him, while his encounters with the Africans who used to work for his father, to whom Marlouw had entrusted their once-prestigious farm, are extremely unsettling. This offers an encapsulation of the western sentiment of Africa as a continent of ruin, lawlessness and poverty,

1 Note that all English translations from the Afrikaans text of Horrelpoot into English are those of Mariette Postma, as no English translation of Horrelpoot was available at the time when the article was written. The article is based on a paper presented at the Second Annual Conference of the Myth Study Group, held in Eshowe, KwaZulu-Natal, in October 2007. 
and also the typical white Afrikaner fears of black domination and retaliation. Deeper yet, the novel powerfully resonates to a white collective memory of guilt. Horrelpoot elaborates on themes of the human condition and the moral horror of colonialism and imperialism depicted in Heart of darkness, but more vividly, presents Marlouw's journey in the present as a metaphorical one, an introspective reflection of an uncomfortable past which is juxtaposed by visions of a bleak and unhappy future of self-imposed exile. Written in a postapartheid context, the novel speaks volumes about the feelings of displacement and estrangement of white Afrikaners who struggle to reassert their own identity.

With more intensified attention to the role of memory following institutions such as South Africa's Truth and Reconciliation Commission, a few introductory remarks on the function of memory in literature should be posed. As will be seen from the discussion that follows, various constructs of memory operate conjunctively in Horrelpoot to display a palimpsestual tension between memory and history. It also shows how memory is socially and historically constituted within differerent contexts. In this sense, Horrelpoot joins the ranks of other postapartheid literature, such as Triomf by Marlene van Niekerk, that reflects different sides of history, memory and guilt. Venter (1996:145) writes in Ek stamel, ek sterwe about the melancholy of the last quiet hour of every day on the farm when all duties are halted at the end of the day, and every person on the farm is allowed an hour of quiet solitude.

Commenting on the role of memory in postapartheid times, Njabulo Ndebele (1998:20) argues that the time is now ripe for South African writers to reinvent South African history through narratives:

Time has given the recall of memory the power of reflection associated with narrative. Isn't it that there is something inherently reflective about memory, as there is about narrative? If so, narratives of memory, in which real events are recalled, stand to guarantee us occasions for some serious moments of reflection.

An example of a recent book that offers a different account of South Africa's past and a "radical new view of the very concept of "history"', is the contribution, The seed is mine, by South African historiographer, Charles van Onselen (Brink, 1998:33). Brink (1998:33) astutely observes that a narrativised past cannot be corrected "by bringing to it the procedures and mechanics and mind-sets that originally produced our very perception of that past". Since memory 
emerges with a series of "blindspots and gaps" (Brink, 1998:37), it is unable to produce a whole so that the imagined rewriting of history should be preferred, writes Brink, adding that the best we can do is "to fabricate metaphors - that is, tell stories - in which, not history, but imaginings of history are invented" (Brink, 1998:42). Memory, however, can clearly not be severed from the notion of forgetting, as every act of remembering involves a selection, a discarding of that which is not chosen (Woods, 2007:17). This dialectic between memory and forgetting inevitably entails the privileging of some memories over others, which, in the case of history, may forge "exclusionary narratives", such as Hegel's notorious exclusion of Africa from "history" (Woods, 2007:13, 23). For Foucault, memory can be used as a counter-hegemonic chronicle in which an imagined "other" history is narrated, destabilising other dominant histories, in other words, creating not only a counter-memory, but also a "counterhistory" (Foucault, 1980:147, 160).

It would be tempting to approach Horrelpoot primarily from a postcolonial or postapartheid vantage point, particularly because of the novel's intentional interplay upon certain themes in Heart of darkness. In Heart of darkness, Conrad poses the question about what makes life worthwhile, what remains in the end. His answer is that only truth remains (Conrad, 1983:69). In this novel about the horror in people, where he sketches the horrors of imperialism and the dangers conjured by the colonial mind, Conrad teaches a lesson that is valid in our time and circumstances. While he writes that people are capable of anything to which they set their minds, we can only nod in meek recognition, having already witnessed the horrors to which he is referring (Conrad, 1983:117).

Horrelpoot, however, similar to Heart of darkness, is also a psychological tour de force of one man's journey into an archaic sphere within his own psyche. This journey in Horrelpoot is mirrored in Marlouw's (parallel) physical voyage to his country of origin and his search for his nephew, Koert. The focus on the psychological forces that drive Marlouw requires a psychoanalytical reading of Horrelpoot. Psychoanalysis, partly a hermeneutic account of memory, attempts to produce a way of dealing with the past rather than revolting against it (Woods, 2007:23). Narrative memory is therefore a useful instrument through which the past is assimilated and integrated into the present. Memory then, according to Johnson (1982:211), is "a term which directs our attention not to the past but to the past-present relation". 
The invocations of memory in Horrelpoot are closely connected with Marlouw's sense of identity and selfhood, as we will show. Horrelpoot sketches Marlouw's retreat into what Jung calls the collective unconscious, the transpersonal inner recesses of the psyche. For Jung, the unconscious comprises of both the personal unconscious (repressed material from everyday life) and the collective unconscious (archetypes) (Jung, 1960b: par. 230). Marlouw's recollections of the past appear to be a continual dialogue with archetypal forces in his unconscious; a continual psychic narrative that Jung describes as "individuation". Rowland (1999:11) describes individuation as "a deconstructive process, privileging the ungraspable unconscious over the limitations of the ego as it continually reshapes identity and perceptions of reality". Individuation demands that one comes to terms with the shadow, in other words, that which is denied in conscious personality. A study of the psyche takes one simultaneously in two opposing and seemingly mutually contradictory directions, namely the one towards freedom of spirit, and the other towards the organic world of instinct, as Jung (1969: par. 380) explains:

Just as, in its lower reaches, the psyche loses itself in the organic-material substrate, so in its upper reaches it resolves itself into a 'spiritual' form about which we know as little as we do about the functional basis of instinct.

Individuation, according to Jung (1960b: par. 432), "does not shut one out from the world, but gathers the world to oneself". Some examples of jungian archetypes are the shadow, birth, child, hero, wise old man and earth mother. The most powerful and perennial ideas in art, religion and philosophy have arisen from these archetypes; they are what Clarke (1992:117) refers to as the typical "key episodes" in the drama of life, "the dramatis personae which are repeated and replayed with infinite variations across the whole range of human history and culture". Horrelpoot takes the reader to one of the most archaic levels of the human psyche, dipping into the timeless stratum of the collective unconscious. Strongly influenced by the writings of Johann Wolfgang Goethe, $\mathbf{2}$ in particular the dramatic poem, Faust, Jung was intensely occupied with the idea of the duality in one's personality and the need to confront and integrate the "shadow" 3 in one's personality. Jung writes that

2 A pivotal figure in German literature (1749-1832).

3 The term shadow was first used by Nietzsche in 1879 in his essay, The wanderer and his shadow when referring to the darker side of human nature. 
[a]bsorption into the instinctual sphere [...] does not and cannot lead to conscious realization and assimilation of instinct, because consciousness struggles in a regular panic against being swallowed up in the primitivity and unconsciousness of sheer instinctuality. This fear is the eternal burden of the heromyth and the theme of countless taboos. The closer one comes to the instinct-world, the more violent is the urge to shy away from it [...]. Psychologically, however, the archetype as an image of instinct is a spiritual goal toward which the whole nature of man strives [...] (Jung, 1969: par. 415).

This will be explored in more detail below.

On one level, in Horrelpoot, similar to Heart of darkness, the characteristics of the "shadow" are attributed to the "dangerous" other faced by both protagonists. The other could be anyone, but in this instance, on the first layer of unconsciousness, the author presents us with descriptions of the so-called "savage" or "primitive" Africans in Conrad's novel and in Horrelpoot the devastatingly poor, hungry and listless blacks for whom every day is a struggle for survival against exploitation by ruthless operators and HIV and AIDS. The Other in both instances is associated with that which is undomesticated, unrestrained and instinctual. It is commonly accepted in psychology that persons, in attempting to rid themselves of undesirable and dark aspects of their own personality, project these onto Others (Deaux \& Wrightsman, 1984:265). In Heart of darkness Marlow's psychological transformation is effected by his journey. Marlouw's experience in Horrelpoot is similar, as will be described below (p. 312). ${ }^{4}$ Both protagonists depart from and return to places described as a contrast to the "dark" continent to which they are travelling: Marlow leaves Brussels in Europe, which is described as a "whited sepulchre" (Conrad, 1983:35), whereas Marlouw leaves his pristine, white Melbourne flat. The first image, in Biblical language, suggests a superficial perfection and hypocritical righteousness which conceals unpleasant, evil darknesses. The image of a sepulchre or burial place indicates on a psychological level, the existence of dead or repressed elements of his psyche. Marlouw's experience of Australia is that the city does not accept him as if he belongs, he does not feel at ease, while his life is ordered on the surface: the surfaces of his kitchen are described as gleaming ( $p$. 28), he feels unwanted and like an impostor (p. 27), even after living in Melbourne for almost twenty years (p. 8-9). Similar images are

$4 \quad$ References cited by means of page numbers only, refer to Venter (2006). 
found in Heart of darkness, where Marlow, at the end of the novel, sees a resemblance between the polished grand piano and a sarcophagus (Conrad, 1983:117).

Some of the constructions of memory portrayed in Horrelpoot will next be considered. An investigation of the manner in which memory translates into history falls outside the scope of this article, as the focus will be on a jungian reading of the text and the extent to which Marlouw's memories influence his progression towards individuation.

\section{Constructions of memory in Horrelpoot}

There were moments when one's past came back to one, as it will sometimes when you have not a moment to spare to yourself. (Conrad, 1983:66.)

Heleen Spies, the sister of Martin Jasper Louw, draws on her intimate knowledge of their shared childhood when she compels her clubfooted $\mathbf{5}$ brother to return to their fatherland and find her son, Koert. After twenty years in Melbourne, Marlouw 6 reluctantly undertakes a terrifying journey during which he travels into his past to face his personal nightmare on Ouplaas, his native land and his family's once-prestigious farm. While he is unwilling to go to South Africa, Marlouw realises from the onset that his life will never be the same again (p. 1). Marlouw, clearly unable to adapt to his "new" country and the people around him, begins to feel a gloomy foreboding, a subliminal stirring that the journey that Heleen forces upon him, is unavoidable.

He realises the inevitability of his impending voyage, and while he has not given Heleen a final answer yet, Marlouw considers his options in a foreign country where he has never felt at home, where he has never been held close to the bosom of the city (p. 8-9). His uneasiness is understandable, as his voyage would lead him to regress to a very deep archaic and arcane level of his own psyche, which, as will be discussed later in relation to Koert, may ultimately end in an eclipse of the ego, resulting in insanity. Jung explains how the dissolution of the ego as a result of the influx of unconscious

$5 \quad$ Known as Talipes equinovarus.

6 "Marlouw" in Horrelpoot is a combination of the protagonist's Afrikaans first names and last name and a deliberate play on Conrad's Marlow in Heart of darkness. 
contents, which cannot be assimilated, may lead to pathological effects (Jung, 1960b: par. 430).

Out in the rain on the bridge it feels to Marlouw as if his disorderly and disjointed thinking wants to imitate the "fluidity" of his surroundings (p. 9). Marlouw has the sensation that he is not moving along himself, but that the wet ground beneath his feet has a compelling direction of its own. Venter here presumably draws on an archetypal image sketched in Heart of darkness where Marlow remarks that travelling on the river towards Kurtz felt like "travelling back to the earliest beginnings of the world" (Conrad, 1983:66). In both novels, the archetypal image of fluidity suggests a need to unite or merge that which is disparate, setting thus the scene for both protagonists, the voyage of both Marlow and Marlouw and the ensuing search for their respective "shadows". The idea of a perilous voyage is a powerful archetypal one that suggests the possibility of death and/or renewal (Cotterell et al., 1999:7).

As Horrelpoot progresses, the reader is gradually drawn into Marlouw's memory of his past on the family farm. Memory, as was alluded to above, is per definition selective, as it consists of both acts of recovery and processes of suppression (Brink, 1998:36). As a result of these factors and others which fall outside the scope of this article, we know that history is not memory (Ricoeur,1955). Marlouw's memories, as will become clear below, will reveal that which he fears as "other" is within himself, as Barbara Gabriel's memory work so strikingly has demonstrated (Gabriel, 2004).

\section{Confronting the Other}

[l]t is impossible to convey the life-sensation of any given epoch of one's existence - that which makes its truth, its meaning - its subtle and penetrating essence. It is impossible. We live, as we dream - alone ... (Conrad, 1983: 57.)

Jung's view of dreams and their directional value can be applied to elucidate many of the symbols and seminal moments in Horrelpoot with a view to the influence of the collective unconscious on the actions of people, and his views on the male (animus) and its female (anima) counterparts. The collective unconscious is similar to a cultural blueprint from centuries back, that is inherited from one generation to the next, explaining an innate understanding of the feelings harboured by our predecessors, an understanding of myths, stories, symbols and the meanings attached to them as well as cultural beliefs. Some of Jung's (1960a: par. 104) archetypes can be found 
in Horrelpoot, such as the hero who faces his past monsters and eventually finds healing in confronting and conquering his feared, repressed self, especially in the form of the anti-hero, Koert, who eventually tells Marlouw, "I am the clubfoot, Marlouw. I am he." (p. 308.) Koert's foot is described in this scene as gangrenous to indicate the extent of destruction, of nightmarish horror. The foot image is discussed in more detail below. Venter's use of concepts like "archfather" (p. 209-210), for example, supports a jungian interpretation of this novel.

Marlouw has tried unsuccessfully to repress and hide his disagreeable memories described as the personal unconscious by Jung, but Heleen, however, knows how to recall these shadowed thoughts of her brother, that have been educated into socially acceptable tendencies, by mentioning specific shared childhood memories to him. It is significant that in stressful situations, whether induced by external disaster or internal emotional upheaval, reason is overborne and a person's conduct is governed by the dominants of his/her inner world (Fordham, 1976:47).

Jung sees a woman (anima) as an archetype of the collective unconscious, who corresponds to a man's (animus) deepest reality, and vice versa (Fordham, 1976:52-53), which explains how Heleen, of all people, knows exactly where Marlouw's specific Achilles' heel can be found. She uses this to set him on his journey to his country of birth, and deeper yet on his journey towards individuation, the process Jung describes as achieving wholeness and harmony of the total personality. Heleen contributes, by forcing him to go in the first place, and by setting him such a herculean task, to Marlouw's difficult travels during which he discovers his true self.

Marlouw's biggest triumph is found in his facing of Koert, who embodies his own shadow, his dark Other. Koert himself expresses the thought that Marlouw may think that he has digressed to an animal (p. 211). Koert, the last male member who could save the family from extinction, also symbolises the worst characteristics ascribed to Afrikaners. He returns to the family farm, after it has been given to the workers, and rules over them without physically or mentally working at any aspect of the farming process himself, referring to himself as King Koert (p. 254), while insatiably gaining more and more power (p. 166-168, 222-223). Koert's profligacy is embodied by Esmie having AIDS. This fact implies sexual infidelity on her side or Koert's, as well as the end of the family name. 
Marlouw, as the jungian archetypal older, wiser person (Clarke, 1992:117), admonishes Koert for becoming the fat caricature of a bastardised Afrikaner who speaks an idiosyncratic language while living a life unworthy of his upbringing. Koert then makes fun of Marlouw, and says that he wants to be left alone, accusing Marlouw of being "stuffed" with a language and an attitude that no longer fit in with Koert's new lifestyle (p. 260).

The meaning of the concept, a club-footed person, will be discussed in the following section, with a view to how this image is central to Venter's text.

\section{The deeper, second-niveau meaning of the club foot}

The vision seemed to enter the house with me ... regular and muffled like the beating of a heart - the heart of a conquering darkness. (Conrad, 1983:116.)

The process of travelling to find Koert, Marlouw's other self, is a difficult one, during which the traveller meets his shadow, faces his demons and chooses to heal (Fordham, 1976:76-82). Marlouw has to conquer his dread about facing the past before setting foot on the plane to South Africa. Even before arriving on the farm itself, Marlouw is faced by many difficulties that he has never had to deal with in first-world Melbourne. The deterioration and suffering that Marlouw encounters alerts the reader to the psychological turmoil that is mirrored in Marlouw's psyche. This is also apparent when the prostitute in the Balmoral hotel tenderly touches and strokes Marlouw's feet, especially the clubfoot, to his initial horror(s) ${ }^{7}$ which later become(s) almost unbelievable:

It was a dream, I thought afterwards. Never before have I felt this way about my foot. Never before have I felt this way. (p. 106.)

The clubfoot, which signifies Marlouw's imperfect self, is his greatest weakness, or Achilles' heel, and throughout the novel his thoughts about the state of his foot reflect his introspection, an analysis of his self or his psyche.

The clubfoot becomes the basic flaw of white men who assume(d) that their role is (was) a superior one. Conrad's reference in Heart of

7 The Afrikaans word horries signifies a state of extreme drunkenness, delirium tremens. 
darkness to a painting made by Kurtz of a draped and blindfolded woman, who carries a lighted torch, is adapted in Horrelpoot to refer to a sketch made by Koert of a small, blindfolded girl who walks with outstretched hands on a surface that looks to Marlouw like a salt plane (p. 105). This archetypal image which is inherently contradictory, containing elements of ignorance (blindfolded women) and that of light or knowledge (torch and bright surface of salt), again alludes to the deeper journey as a prelude to the confrontation with the "shadow".

Jung holds that animus and anima mediate between the conscious and unconscious mind, giving the person seeking wholeness and opportunity to understand the unconscious by means of dreams (Fordham, 1976:58). In Horrelpoot, the anima is represented by various female characters, of which Heleen and Mildred represent those closest to Marlouw, with Esmie Phumzile representing Koert's Other.

In Horrelpoot, Marlouw represents the collective unconscious, the feelings of guilt experienced by centuries of postcolonial farmers in South Africa. The awareness and associated guilt of being impostors may explain the collective guilt that feeds umpteen myths in a postcolonial country such as South Africa, where white people dream, tell and live urban legends and myths about their being slaughtered and murdered by "them", the dark personification of the white person's suppressed morality, the "others". This "othering" of people is not new, and was not exclusive to imperialists in the 1800s. The Greeks called people in countries they had invaded and conquered, barbarians. The word is still used today to depict a lack of civilisation and finesse, a wildness. The process of viewing people as others, of imposing an own set of rules onto them, is, however, still applied millennia later by ignorantly yet energetically "teaching" new "rules" while denying an existing, an often more developed culture.

The loss of their perfectly planned empire and the breaking down of their well-oiled machine of technology on the previously undeveloped continent embodies the collective fear of some white Afrikaners in South Africa, bleakly yet convincingly real in Venter's Horrelpoot. Marlouw dreads his imminent and inevitable travelling into the very heart of the darkness he wishes to escape, like Marlow in Heart of darkness travelled to the Congo, about a century before him, but with the same fear of what he may find. Upon arrival Marlouw, like Marlow before him, finds that his greatest fear has been surpassed by the unimaginable evil of humankind. The hardships of 
travelling into unknown and unkempt Africa become immaterial in the face of the moral onslaughts on the psyche of the traveller.

He prefers his own company to that of others, showing little interest in his family ties, even though as a male Louw, he could be the heir and continue the family bloodline himself, Marlouw never considers this possibility but instead hands over the deeds of the farm to the African farm workers at his father's funeral. His father, portrayed as the archetypal, robust and morally "correct" Afrikaner farmer cherishes the Afrikaner obsession with bloodline, where sons are more important to the family and procreation than daughters. For Jung, the archetypal father is the "representative of the spirit, whose function it is to oppose pure instinctuality" (Storr, 1973:48). As indicated above, Marlouw's discovery of his father's infidelity shows the need for the integration of the dark and instinctual part of himself. This could be interpreted as the way forward, integrating themselves with their shadows, effecting individuation or peace.

\section{Dreams, myths and nightmares and the collective unconscious}

It seems to me I am trying to tell you a dream - making a vain attempt, because no relation of a dream can convey the dream-sensation ... that is the very essence of dreams ... (Conrad, 1983:57).

Different dreams from the collective unconscious are discussed throughout the novel, to indicate the fear inherited from one generation of privileged farmers to the next. Postcolonial families live by their own rules, and each night when the sun sets, they feel satisfied about having tamed the earth they have claimed for themselves. Farm workers are seen as a commodity, as a part of nature that they feel responsible for taming and breaking in, just as they clean the earth when planting, they "teach" the Africans to live and view life their way, the right way. Their work on their land is seen as a calling, and they give their sweat to this earth in the belief that they are fulfilling their lives as they should.

With this life-view comes its own sets of myths and beliefs, and in the jungian sense, as Venter illustrates, its own dreams that are still haunting Afrikaans people in South Africa a century after Conrad's narration of white fear in Heart of darkness. Venter indicates the irony of postcolonial impostors who dread losing their minds, their health, their possessions to these "monsters" that they have created in the first place (p. 22). 
Marlouw asks Jocelyn, Heleen's "imported" houseworker from South Africa, to help him look into his future, remembering how his mother used to trust signs. Jocelyn takes his right hand and sees an enormous rugby field with players. The playing field is the same, but the game no longer follows any rules (p. 16-23). Since rugby is a game where the foot is an integral part of playing, Marlouw knows that she is really referring to his foot, but does not want to say so directly (p. 22). She informs Marlouw that Koert has digressed himself, and that he will return only if he decides to do so, that the matter cannot be forced. Marlouw thinks that Jocelyn could have been his mother, and feels loved by her. Jocelyn is knitting an object, using black wool, an image that resembles the knitting women that Marlow encounters in Heart of darkness (Conrad, 1983:3536). This image significantly points to the impending journey, with the yarn (thread of life) spun in black. Note the comparison with the mythological Fates (from the Roman Fatae, in Greek known as the Moerae), who were three goddesses who spun a length of yarn which represented the allotted span for each mortal (Cotterell et al., 1999:43-44). In Horrelpoot, these three, known by the Greeks as Clotho (the spinner), Lachesis (the apportioner) and Atropos (the inevitable) would be represented by Heleen, Jocelyn and Mildred, the three females who steer Marlouw's journey to individuation.

Marlouw tells Jocelyn that he knows he has to undertake the journey, and she repeats that Marlouw should remember that Koert has taken himself on a different road. Jocelyn also warns Marlouw that he is not returning to a soft, friendly country where people are going to welcome the white master, nor respectfully allow him any rights as in the past. She reminds him that a cripple's life is not worth much once he is as down and out as "they" are, that the other people seen as weak; mothers, young girls and children are reportedly dying there every day (p. 23-24). Jocelyn finally asks Marlouw whether he has the mental strength for facing parts of his hitherto revealed self, and adds that they have to give Heleen hope and hide reality from her (p. 23).

Horrelpoot skilfully emphasises some deeply entrenched South African myths. Like the Germans and the Dutch from whom Afrikaans people descend, efficient organisation, such as a smoothlyoperating infrastructure is often valued as proof of having tamed the wildness in Africa. A breakdown in the predictability of the transport and communication system as soon as it falls into the hands of the other, or Africans, is one of the myths in which some Afrikaans 
people firmly believe. 8 Their biggest nightmare comes true when reading about Marlouw's difficulties to travel from first-world Melbourne into the heart of darkness, first by air via Fidji to Johannesburg, from there to Bloemfontein and then on land to the Eastern Cape. In Heart of darkness Marlow makes the observation that they are penetrating "deeper and deeper into the heart of darkness" (Conrad, 1983:68), indicating the primal world that is entered.

Tired, Marlouw realises that his presence in "that" other country is redundant and unimportant (p. 93), and that he must have looked flustered, and caught on the wrong foot at the hotel in Aliwal North. To Marlouw, the people in the hotel look "like the earliest people on earth" (p. 99), guileless, and he is convinced that he has arrived in the midst of Koert's people, where he is happy but does not really belong himself. This particular image marks Marlouw's psychological descent to a deeper level of unconsciousness; he is is getting closer to the deepest and darkest inner core of his psyche.

At this hotel, Marlouw decides to enjoy the moment, to stop creating order and let go of his ghosts. Venter describes the local people and nature as Marlouw's enemy, always taunting him. The self-sacrificing Scandinavian, like forgotten memories of Koert, become the delusion against which Jocelyn has warned him, and he decides not to allow these memories, but rather to drown them in whiskey ( $p .99-$ 101). He wants to remember the abundance of nature after the rain in all its glory, only one more time, suppressing negative thoughts and memories (p. 108). Marlouw wants to arrive unseen, anonymously, but does not succeed in suppressing the words "imposter" 9 and "funk" (p. 110) and decides that he will deal with the slowly approaching fear or funk later. Marlouw frequently senses the dreaded, foul-smelling ghosts that keep haunting him and cannot be found, and realises that his taxi driver also saw them and feared them (p. 78).

One of Koert's closest assistants is Pilot, a flashy, young black man who frequently taunts Marlouw by miming his words (p. 114, 127). Pilot's name is deceptive, as he is without direction and the exact opposite: his only purpose is to please and serve Koert, from whom he occasionally receives gifts in the form of liquor, blue-tinted

8 For some, looking at the rest of Africa, this fear has turned into reality, which in turn lends credibility to this general stereotype.

9 The "e" in impostor (eg "imposter") is American spelling. 
sunglasses and golden running shoes (p. 112, 138). Pilot is Koert's antithesis and resembles the son of the Russian archpriest in Heart of darkness to whom Marlow refers as Harlequin. As the archetypal harlequin in Horrelpoot, Pilot often surprises Marlouw with inappropriate responses, such as childish behaviour in serious situations and the opposite in humorous moments (p. 193). As one of Koert's most devoted disciples, he represents ignorance, irreverence and blind loyalty, characteristics at odds with Marlouw's journey of individuation. It is therefore no surprise that with Koert's demise, he also disappears back into darkness (p. 309). The last section looks at this darkness, where the own shadow is faced or confronted.

\section{Confronting the "shadow"}

I was anxious to deal with this shadow by myself alone and to this day I don't know why I was so jealous of sharing with any one the peculiar blackness of that experience. (Conrad, 1983:105.)

It is clear from the beginning of Horrelpoot that Marlouw is the deeply unhappy and conflicted "hero" who has no choice but to undertake the journey to his country of birth. Although having "escaped" the tragedy and devastation of events unfolding in South Africa after they had left the country, Marlouw does not feel at home in Australia. His estrangement and feeling of displacement on both his native continent and Australia are powerfully presented throughout the novel (p. 163), reinforced by the use of the light-darkness theme. His personal defrayment is mirrored in the general physical defrayment, deterioration and decay that surrounds him (p. 220).

At the climactic moment, Koert tells Marlouw that he, Koert, is the clubfoot, the cripple himself, and as Marlouw nods, Koert is fatally wounded, after which he is stabbed by everybody in an almost anarchic ritual (p. 308-309). Koert's dying words confirm the utmost horror (horrel), and his body falls down, granny Zuka ululates with a foaming mouth and gives the farm worker, Headman, a burning porcupine head to throw through the windows of Koert's quarters.

Koert's final words, echoing those of Kurz in Heart of darkness ("The horror! The horror!"; Conrad, 1983:111), suggests final self-knowledge and is a paradoxical victory, paid for by unspeakable horror and inner anarchy. It is evident from this final scene that the stronger and closer Marlouw gets to confronting his darkest inner core, the weaker the crawling and spit-dribbling Koert becomes, and the less 
significant Koert's power over Marlouw (p. 306-308). Finally, introspection could lead to insight, as is indicated below.

\section{Conclusion}

I looked around, and I don't know why, but I assure you that never, never before, did this land, this river, this jungle, the very arch of this blazing sky appear to me so hopeless and so dark, so impenetrable to human thought, so pitiless to human weakness. (Conrad, 1983:94.)

The various memory constructs in Horrelpoot are finely interwoven with vivid jungian archetypal images, the latter in existence in all people since time immemorial. Venter draws on these primordial recollections in order to facilitate one man's journey towards individuation, an opportunity to find meaning. While it does not offer ultimate answers or perfection, it suggests a realistic goal of personal transformation and growth, of self-realisation and integration.

The characterisation in Horrelpoot can be interpreted as a logical syllogism, where Marlouw searches the horror as he travels into the heart of darkness, and is shocked to the core when he encounters this horror or evil in Koert, his blood relation (p. 235). Assisted by his dead father who appears to him and reminds him of the family nightmare that is found in their collective unconscious, Marlouw assumes that he will find the horror in those he views as the impostors, the others, Africans living on his family farm, and he fears the evil ways in which witchcraft, personified especially by granny Zuka, could harm him and his family members, albeit only their buried physical remains. Marlouw's utter horror at his final realisation concludes the last leg of the syllogism, when he declares that he is Koert, and that he himself, is the horror.

Marlouw denies his true self, who he is below the surface, projecting the horror of his ungainly tread onto Koert. His negative self is projected so that Koert, his other, becomes the epitome of evil and can be seen to represent white intrusion and imperialism in Africa. Marlouw's journey takes on the form of a circle, with all the accompanying meanings attached to a circle - the journey is fulfilled, in a sense, closure is reached upon the completion of his individuation process. Once he realises that the heart of darkness is seated within himself, that he himself is the real horror, Marlouw grasps after leaving the farm and the embodiment of his worst self behind, that there is nothing else to fear. He has looked inside, and he saw the beast living inside his own heart. 
On a more superficial level, Marlouw's experience and his return to his self-imposed exile in Australia may point to the conflicting emotions of white "Afrikaans" people who need to confront their own deep and dark past, the horror that lies at the bottom of their own lives and history. Jung's idea of individuation, however, rests on the assumption that perfection is not possible. The vicissitudes of the journey itself, rather than some ultimate destination, make the journey worthwhile (Jung, 1960b: par. 771). It is therefore the self-discovery, however disgusting and disappointing this may be, that constitutes change. While it is no longer possible to reverse the onslaught of imperialism on Africa, introspection could effect inner change and in time, perhaps also healing, albeit painful when the shadow, the core or inner heart of darkness, is confronted. The final image in Horrelpoot of the once prestigious farm totally deserted by humans with small animals gradually returning (p. 321-323) shows a peaceful picture which may be interpreted as either depicting the earliest times when man has not yet existed, or alternatively, an apocalyptic one showing the world that will remain after man has gone.

\section{List of references}

BRINK, A. 1998. Stories of history: reimagining the past in post-apartheid narrative. (In Nuttall, S. \& Coetzee, C. Negotiating the past: the making of memory in South Africa. Oxford: Oxford University Press. p. 29-42.)

CLARKE, J.J. 1992. In search of Jung: historical and philosophical enquiries. London: Routledge.

CONRAD, J. 1983. Heart of darkness. London: Penguin.

COTTERELL, A. \& STORM, R. 1999. The ultimate encyclopedia of mythology. London: Hermes.

DEAUX, K. \& WRIGHTSMAN, L.S. 1984. Social psychology in the 80s. Montery: Brooks/Cole.

FORDHAM, F. 1976. An introduction to Jung's psychology. Harmondsworth: Penguin.

FOUCAULT, M. 1980. Language, counter-memory, practice: selected essays and interviews. Edited by D.R. Bouchard. Ithaca: Cornell University Press.

GABRIEL, B. 2004. The unbearable strangeness of being: Edgar Reitz's heimat and the ethics of the unheimlich. (In Gabriel, B. \& Ilcan, S., eds. Postmodernism and the ethical subject. Montreal: McGill-Queen's University Press. p. 149-202.)

JOHNSON, R. et al., eds. 1982. Making histories: studies in history-writing and politics. London: Centre for Contemporary Cultural Studies.

JUNG, C.J. 1960a. Collected works. Vol. 7. Trans. by R.F.C. Hull. Edited by H. Read, M. Fordham \& G. Adler. London: Routledge.

JUNG, C.J. 1960b. Collected works. Vol. 8. Trans. by R.F.C. Hull. Edited by H. Read, M. Fordham \& G. Adler. London: Routledge.

JUNG, C.J. 1969. On the nature of the psyche. Trans. by R.F.C. Hull. Edited by H. Read, M. Fordham \& G. Adler. London: Routledge. 
NDEBELE, N. 1998. Memory, metaphor, and the triumph of narrative. (In Nuttal, S. \& Coetzee, C., eds. Negotiating the past: the making of memory in South Africa. Oxford: Oxford University Press. p. 19-28.)

RICOEUR, P. 1955. History and truth. Trans. by C.E. Kelbley. Evanston: Northwestern University Press.

ROWLAND, S. 1999. C.G. Jung and literary theory. Hampshire: Palgrave.

STORR, A. 1973. Jung. Glasgow: Fontana.

VENTER, E. 1996. Ek stamel, ek sterwe. Kaapstad: Queillerie.

VENTER, E. 2006. Horrelpoot. Kaapstad: Tafelberg.

WOODS, T. 2007. African pasts: memory and history in African literatures. Manchester: Manchester University Press.

\section{Kernbegrippe:}

geheue na 'n eeu van vergeet

herinnering, konstruksies van

jungiaanse reis na individuasie

postapartheid Afrikaanse letterkunde

\section{Key concepts:}

jungian journey towards individuation

memory after a century of forgetting

memory, constructs of

postapartheid Afrikaans literature 